\title{
Artistic scarcity in an age of material abundance: President Lyndon Johnson, the National Endowment for the Arts, and Great Society liberalism
}

Karen Patricia Heath, University of Oxford

\begin{abstract}
1965 saw President Lyndon Johnson push an incredible number of reform bills through Congress as part of his quest for a Great Society - including legislation to create a National Endowment for the Arts (the federal agency that provides grants to artists and arts organizations in the United States). Public confidence was riding high, the economy was good, and Americans demonstrated a remarkable faith in the capacity of the federal government to solve domestic problems. And yet in this age of abundance, Johnson drew on the rhetoric of scarcity to promulgate his domestic policy. When the President spoke of the cultural aspects of the Great Society he typically emphasized qualitative and quantitative goals, i.e. the power of the arts to improve the quality of life of ordinary Americans and to reduce a perceived imbalance between the haves and the havenots. Whereas other studies have relegated the cultural aspects of the Great Society to the sidelines, this study places such matters centre stage through an analysis of the rationales behind the creation and early programming of the Endowment. In so doing, it illuminates the inherent contradictions of, and tensions within, American liberalism in the mid-1960s.
\end{abstract}

\section{Keywords}

Great Society

liberalism

Lyndon Johnson 
National Endowment for the Arts

scarcity

It is in the neighborhoods of each community that a nation's art is born. In countless American towns there live thousands of obscure and unknown talents.

What this bill really does is to bring active support to this great national asset, to make fresher the winds of art in this great land of ours.

The arts and the humanities belong to the people, for it is, after all, the people who create them. (Johnson 1965)

On 29 September 1965, President Lyndon Johnson signed the National Endowment for the Arts, - the federal agency that provides grants to artists and arts organizations in the United States into existence. In a ceremony held in the White House Rose Garden, the President spoke with optimism of the United States as a place where the 'obscure and unknown talents' of potential American artists would now receive federal encouragement and stimulation, a country where cultural endeavours might be recognized as a truly 'great national asset', via a bill that sought to invigorate 'the winds of art in this great land of ours' (Johnson 1965). The rhetorical force of these ambitious words was a very serious matter for Johnson, more so than the substantive commitments they were intended to convey, namely idealism, and the transcendence of materialistic concerns. Johnson's rhetoric also evoked the national spirit that James Patterson 
describes so well in The Eve of Destruction (2012): there was a feel-good atmosphere, a sense of incredible confidence and a penchant for grand dreams in the mid-1960s (Patterson 2012: 1-2). The President, however, drank from a rhetorical well of scarcity in this age of abundance when he spoke of how the Endowment would recognize hitherto 'obscure and unknown' artistic talents and bring the fruits of these aesthetic pursuits to all Americans, 'for it is, after all, the people who create' (Johnson 1965). In so doing, Johnson emphasized both the qualitative and quantitative cultural goals of his Great Society domestic programming: in short, he embraced the ability of the arts to enhance the nation's quality of life, whilst also increasing the production of, and access to, varied artistic forms; and in so doing, boosting the number, and material wealth of, American artists.

That said, Johnson personally was not much interested in the acquisition of knowledge, cultural or otherwise, for its own sake, nor did he have time for art appreciation or meeting with artists: rather he appreciated power, and its application, to achieve his political ends, and he held a grandiose conception of the historical moment that he inhabited. When the President had initially set out his domestic goals back on 22 May 1964 in the commencement address at the University of Michigan, Ann Arbor, he had envisaged the Great Society as a place where the ordinary American would enjoy cerebral activities, 'enrich his mind' and 'enlarge his talents', find time for reflection and the opportunity to satisfy a natural, deep-seated 'desire for beauty', but he had failed to mention the arts specifically (Johnson 1964a). Rather, his primary domestic goals were to end 'poverty and racial injustice', i.e. to stop poverty in its tracks, and provide civil rights for African Americans (Johnson 1964a). Johnson did not consider the arts, be it painting, sculpture, theatre, music, literature or poetry, to be central to his own life either, because he was obsessed with politics, and thought of little else. 
At heart, Johnson's Great Society was concerned with providing for the general welfare of the American people, with the central idea being that the federal government ought properly to play a role in this (and indeed almost any) endeavour. This was a new form of liberalism, a Great Society liberalism that emerged at a special moment in American history, at a time when a great many things seemed possible. Liberalism was moving towards qualitative as opposed to purely quantitative issues, and now placed an onus on quality of life concerns, as well as the material needs so emphasized by President Franklin D. Roosevelt's New Deal of the 1930s. This was not surprising: Arthur Schlesinger Jr. (1956: 8-11) had already predicted a turn towards qualitative liberalism as early as the mid-1950s in an article published in The Reporter magazine, whilst John Kenneth Galbraith had investigated similar problems of abundance in The Affluent Society (Galbraith 1958). Although Johnson admired Roosevelt and wished to replicate the New Deal in certain ways, the onset of affluence and the backdrop of national confidence in the mid-1960s dictated a very different kind of liberalism. It also resulted in the creation of the nation's first permanent cultural agency with grant-making powers.

Presidential historians have often overlooked Johnson's ideas concerning the arts; an understandable oversight, given that Johnson himself did not even mention the subject in his memoirs (Dallek 2004; Andrew 1998; Johnson 1972). Thus whilst a large historical literature analyses the federal government's cultural Cold War activities - principally the programmes of the Central Intelligence Agency, the United States Information Agency, and the State Department - and another explores the impact of Red Scares in the arts during the same time period, as yet, no similar body of work offers an in-depth examination of the cultural aspects of the Great Society (Saunders 1999; Krenn 2005; Von Eschen 2004; Caute 2008; de Hart Mathews 1976; Fried 1990: 30-36; Schrecker 1998: 401-403). The story of the Endowment's origins and 
early programming has thus been left to scholars of federal arts policy-making: Donna Binkiewicz, for example, has emphasized the significance of the "[i]deological and political influence of the Cold War” in shaping the nascent Endowment (2004: 2, 4, 30, 33, 60, 63, 6668), but it was actually the language of the Great Society that dominated debates over the federal role in the arts in 1965, the year that saw the creation of the National Endowment for the Arts, and one that was in many respects ground zero - a radical departure for the federal government.

This article therefore explores the qualitative and quantitative liberal ideals that underpinned the creation of the Endowment, the political and budgetary threats (and a few opportunities) the first Chairman faced, the agency’s early efforts to deliver on Great Society goals, and the problems the Endowment ran into when the Vietnam War began to constrict the availability of funds. In so doing, it illuminates the inherent contradictions of, and tensions within, American liberalism in the mid-1960s.

\section{The birth of the National Endowment for the Arts}

The National Endowment for the Arts could only have been signed into law at a very particular moment in time - 1965. At the height of the Great Society era it seemed that experts now ran the country, as the 'best and the brightest', from the social sciences and the humanities, were tapped by Johnson to sit on an ever-expanding number of task forces (Halberstam 1972). Concerns about artistic scarcity, be it the material needs of American artists, or lack of public exposure to the arts, were now taken seriously by American elites, as demonstrated by the research into these problems undertaken by major philanthropic organizations, such as the Rockefeller Brothers Fund (1965), and the academic work of economists, most notably William J. Baumol and William G. Bowen (1965: 500; 1966). 1965 then, was a moment of 'grand expectations' when 
anything seemed possible, even federal aid to the arts. It was the high point of Great Society liberalism, and Johnson pushed an incredible number of reform bills through Congress, including the Endowment (Patterson 1996: 588).

Initially though, Johnson had emphasized that the building of the Great Society would take place 'in our cities, in our countryside, and in our classrooms' - not in America's theatres, museums or galleries (Johnson 1964a). But although the arts were never a priority for the President, in Congress, legislative efforts were inspired by the grandiose rhetoric of the Great Society, Johnson's vision of improving the quality of life for Americans on their own soil, and delivering on concerns about artistic scarcity. After Johnson soundly defeated that inordinately conservative Republican Senator from Arizona, Barry Goldwater, in the presidential election of 1964, the Democrats were returned to Congress with large majorities in both houses: 295 in the House and 68 in the Senate. The ideological composition of this 89th Congress thus saw a new liberal supremacy replace a conservative hegemony. Key federal arts supporters included Representative Frank Thompson Jr. of New Jersey and Senator Claiborne Pell of Rhode Island on the Democratic side, plus Senator Jacob Javits, a liberal Republican from New York. Throughout the late 1940s and 1950s, these Congressmen and a very few others like them, had tried their best to push through domestic arts funding legislation, but these attempts had come to naught (Binkiewicz 2004: 21-23). Prior to the coming of the Great Society, legislators had been more interested in using the arts as a cultural weapon abroad or as a political one at home, than in addressing the financial wants of American artists, or the aesthetic needs of their audiences.

Ultimately, 1965 saw five congressional federal aid to the arts bills with differing emphases on the visual and performing arts, and the arts and the humanities (Aarons 1965: C20). Joint House and Senate hearings were held, but there was an air of indecision to the proceedings 
as the White House remained quiet on the subject. 1965 was a busy year for the President that saw the passage of the Elementary and Secondary Education Act, the Social Security Act (that included Medicaid for the elderly and Medicare for the poor), the Voting Rights Act, and the Housing and Urban Development Act, and the arts were simply not a priority. Even at this point, at the height of the Great Society reforms, presidential support for federal aid to the arts was not guaranteed.

When Johnson finally did send a bill to Congress for two autonomous Endowments, under the aegis of a National Foundation on the Arts and Humanities, the legislation provided just \$21 million to be divided equally between the arts and the humanities: a tiny, almost token amount (National Foundation on the Arts and the Humanities (NFAH) Act 1965 1966: 845). The measure easily passed the Senate on voice vote, but was blocked in the House Rules Committee until the new 21-day rule was invoked, and a majority brought the bill onto the House floor (Hunter 1965: 27). After three hours of debate and votes on several amendments, the House finally approved the bill (Anon. 1965: D20.) A conference committee was then held to reconcile the House and Senate versions. The final bill, signed by the President on 29 September 1965, was a solid piece of Great Society legislation, and it was accompanied by complementary rhetoric. As Representative Adam Clayton Powell, the Democratic Chairman of the House Education and Labor Committee put it, the time had come for 'nourishing our culture as well as our economy', there was more to life than just materialism, and the Endowment would enhance the quality of life of all Americans (1965: 23937).

In practical terms, the National Foundation on the Arts and Humanities Act of 1965 created a hierarchical structure for the award of federal arts grants. At the top stood a Federal Council on the Arts and the Humanities, an umbrella body comprised of high-level cultural 
appointees who would coordinate federal activities. The National Endowment for the Arts, and a sister agency, the National Endowment for the Humanities, both resided at the next level down. Within these two bodies, a Chairman (appointed by the President with the consent of the Senate) was authorized to 'establish and carry out a program of grants-in-aid to groups or [...] individuals engaged in or concerned with the arts’ with the advice of a National Council (made up of 26 leading individuals from the arts world, selected by the President), and the assistance 'from time to time' and 'as appropriate' of external consultants and 'panels of experts' (NFAH Act 1965 1966: 846, 849, 851-52, 855).

The act also stated that 'encouragement and support of national progress' in the arts was ‘an appropriate matter of concern' for the federal government. It added that the Endowment was designed to deliver qualitative benefits (by bringing the arts to those Americans who 'without such assistance' would be unable to enjoy them) whilst also producing quantitative effects (by improving the 'material conditions' of the American artist) (NFAH Act 1965 1966: 845, 847). The language of the bill thus indicated a strong belief in state activism and the idea that the federal government ought to do good things. The Endowment was born of the Great Society moment, and it merged qualitative and quantitative liberal goals, for it was designed to improve the lives of both ordinary Americans and artists alike by using the power of the federal government to reduce a perceived imbalance between the haves and the have-nots.

\section{The politics of art at the height of the liberal moment}

Still, neither the new Endowment, nor the arts per se, were of central concern to the vast bulk of the Democratic Party in the mid-1960s, even though the Democrats had accepted a platform that spoke of federal support for the arts at their 1964 convention in Atlantic City, New Jersey 
(Democratic Party 1964). In 1965, this lack of support mattered little, because the economy was strong, and liberalism was at high tide, but in 1966, Republicans made significant gains in the midterm elections, and by 1968, the national economic climate had constricted to the extent that cost-cutting and issues of fiscal equity replaced worries about artistic scarcity (i.e. a lack of public access to the arts and a dearth of support for artists). The later 1960s were accordingly inhospitable budgetary years for the Endowment: Congress was preoccupied with the guns and butter debate - how to fund both the war in Vietnam and the Great Society - and was thus determined to cut away every remaining scrap of political pork. As Joseph Califano, Johnson’s senior domestic policy aide later noted, the Endowment was 'particularly vulnerable' to economic pressures because the agency was not a core part of the Great Society (Califano Jr. 1991: 142). The Endowment’s first budget for fiscal year 1966 was less than $\$ 3$ million: this represented just 0.002 per cent of a total federal budget that stood at $\$ 134.5$ billion. Thus, although the Endowment's budget grew to nearly $\$ 8.5$ million in fiscal year 1967, this growth was not destined to continue, as Congress cut the agency’s appropriations back to just over $\$ 7.5$ million for fiscal year 1968. The agency's appropriations recovered somewhat for fiscal year 1969, when Congress appropriated nearly $\$ 8.5$ million (a total almost commensurate with the sums for fiscal year 1967), but still, this was a tiny sum (National Endowment for the Arts [NEA] 2016; Wallis 2006: 105). The budgetary climate grew increasingly difficult for the Endowment as the end of the decade drew closer, and yet these problems of fiscal scarcity were not the least of the agency's worries.

Like other Great Society programmes, the Endowment did not represent an obvious response to significant public demand because the agency was the product of the expert politics of a small liberal minority in Congress. Put simply, few Americans saw the need for the federal 
government to resolve perceived problems of artistic scarcity, whether in terms of public access to the arts, or the material needs of artists (Jacobs 1967: 25). The creation of the Endowment thus failed to generate much excitement amongst the populace in general, and only certain union members in the arts, plus a few public intellectuals, actively supported the agency once legislation was passed. Other elements of the liberal coalition, most notably African Americans, women, urban ethnics, reformist professionals, western infrastructure Democrats, and a few big city machine politicians, were not politically moved by federal aid to the arts. Although when the mainstream press did discuss the agency, the coverage was generally positive - writing in The New York Times, Howard Taubman (1966: 31) praised the Endowment for taking bold, creative risks, as did Wolf Von Eckardt (1966: G9) for the Washington Post - these articles were few and far between, and were generally buried in the middle of the paper, or in separate arts inserts. As Larry Sabato has characterized it, the media 'lapdog' role (a generally deferential approach towards the political establishment), was beginning to change in the mid-1960s, and a more adversarial press was forming, but as yet, the newspapers were not looking for ways to profoundly embarrass or antagonize political elites, nor to ridicule or undermine their policies, meaning that little public debate surrounded the birth of the new agency (1991: 26, 42-44, 49).

The creation of the Endowment did stimulate the arts world, but this lobby was still relatively weak: as Frank Getlein, the art critic for The New Republic remarked in 1965, there was not 'any American art community in that sense', for a coherent interest group did not yet exist (1965: 27). Robert Brustein, the theatre critic for that same magazine, also sounded less than enthused about the Endowment, for he feared that mixing art and politics would result in a 'loss in spontaneity and conviction, and a corresponding gain in hollowness, swank and phony glitter', whilst the film producer John Houseman worried that federal support for experimental 
art would deaden the radical nature of the avant-garde (Brustein 1964: 85; Seidenbaum 1965: D9). More impecunious artists desperately needed funds to buy materials, rent space to work, and allow time away from their day-jobs to devote to their art: de facto, some artists sought what the poor wanted, i.e. direct subsidy, yet those of a free-market persuasion, especially art dealers, thought that federal patronage would adversely affect their business and upset the natural ecological balance of the art market (Rose 1967: 34; Jacobs 1967: 28). The general attitude of the arts world in the mid-to-late 1960s was thus fearful, sometimes distrustful, and on occasion, outright resentful: a not unsurprising situation, given the problems many artists and other cultural folk had experienced in the earlier Cold War years when some were subject to Red Scare attacks, whilst others saw their work repurposed by the federal government to symbolically assault the Soviet Union (de Hart Mathews 1976; Barnhisel 2015). The Endowment was therefore in a difficult position from the beginning, precisely because both the qualitative and quantitative benefits of federal aid were far from obvious to a disparate arts constituency that viewed the agency's first steps onto the political stage with suspicion. Besides, little thought had been given during the enactment phase as to exactly what the Endowment would actually do - it was mainly grandiose political rhetoric, and Johnson was in a hurry to pass legislation before the political winds turned against him. There was accordingly little indication that the Endowment was welcomed onto the artistic scene with outstretched arms, or even a basic willingness to look to the federal government for beneficence to support the production of new art forms.

That said, Johnson's choice of the first Chairman to head up the Endowment and oversee the agency's new programmes - Roger L. Stevens (b.1910-d.1998) - was an excellent one. A Democrat with an impressive record as a party fundraiser, Stevens was a wealthy man who had made his money in the real estate business: such deals funded his second career as a Broadway 
producer (Norton-Taylor 1966: 152). Like Johnson, Stevens was a self-made man who had experienced both material and cultural poverty in his youth: he looked back on the New Deal programmes with fondness, and towards the Great Society ones with hope (Kahn Jr. 1954: 42). Stevens was not an intellectual (Johnson was wary of these deep thinkers), he was instead a practical businessman who understood politics, a man of action (the kind that Johnson personally preferred) and the two got along very well, as the photograph below indicates. Stevens therefore seemed a perfect candidate to lead the agency, for his background was similar to the President's, as were his values and overall sensibility. Given the problems of fiscal scarcity that the Endowment was to face as the Vietnam War threatened the budgets of new Great Society agencies, the President's personal support was going to be essential.

\section{***INSERT IMAGE 4315-27a_300.tif HERE***}

\section{Image caption:}

Figure 1: Chairman Roger Stevens meeting with President Lyndon Johnson in the Oval Office (Smith 1967). Image credit: LBJ Library Photo by Kevin Smith.

Nevertheless, Stevens' nomination as Chairman met with severe disapproval from certain elements of the arts world: the novelist Philip Roth spoke publicly of the appointment as 'shocking', whilst an unnamed philanthropic figure complained to Newsweek that Stevens was 'too much of an operator' (Jacobs 1967: 25; Anon. 1966: 38). Influential figures in the arts worried that Stevens might advance his own personal interests and favour the performing arts to the detriment of any other art form: and yet Stevens also encountered criticism from the 
theatrical world too, as the not-for-profit theatre community questioned his artistic credentials. With Broadway hits to his name, such as Tennessee Williams' Cat on a Hot Tin Roof (1955), Stevens was simply too 'right-wing' for labour-oriented drama critics such as Martin Gottfried of Women's Wear Daily (Gottfried 1969: 62). Stevens was thus (initially) personally unpopular with some members of the precise constituency that he was supposed to be representing. (That said, a degree of criticism from one or more sections of the arts world was probably to be expected no matter who Johnson nominated, given the general wariness many cultural folk displayed towards the federal government's aesthetic activities).

As Chairman, Stevens therefore needed to keep the Endowment out of trouble with both the Johnson White House and Congress, whilst at the same time, reach out to build bridges with a suspicious arts community. Looking back explicitly to the old New Deal paradigm would not have worked, for those federal arts projects were temporary, not permanent, became mired in controversy, and were gutted by congressional conservatives long before World War II arrived to drive the final nail into the coffin. Nor would it have been wise to explicitly revisit earlier Cold War debates for this would have alienated the agency's core constituency, and in so doing, undermined the new federal programme. However, this lack of any explicit model to follow actually permitted Stevens a considerable amount of latitude. His free-wheeling style and ability to make deals were exactly what the agency needed in the early days to make any headway with such a small amount of money. The Endowment’s tiny budget - less than \$3 million in fiscal year 1966 - thus, conversely, helped the agency at the start. With a scarcity of funds, neither Congress nor the arts world could not expect the Endowment to make much of a difference to the lives of either the American public, or the nation's artists, at least at the beginning. This meant 
that the agency was initially able to operate on a trial and error basis without running into problem of abundance, i.e. excessive expectations.

\section{Great Society theatrics}

In the earliest days of Stevens' chairmanship, Endowment grants were made on an ad hoc basis. The agency's first annual report in fiscal year 1965 thus offered an overview of the state of the arts in America, but no breakdown of grants, whilst the second annual report in fiscal year 1966 covered only a nine-month period from the enactment of the enabling legislation, not a full year (NEA 1965, 1967: 2). Solid (and comparable) programme figures for Stevens' tenure are, therefore, only available for fiscal years 1967-68 (NEA 1968: 51, 1969: 63). During these final two years however (Stevens departed when President Richard Nixon took office in 1969), the Endowment channelled more funds to the American theatre than any other single art form - in fact, the theatre consistently received nearly a quarter of the agency's programme funds (approximately $\$ 1$ million in fiscal year 1967, rising to nearer $\$ 1.5$ million in fiscal year 1968).

Federal aid to the theatre made good political sense for the Endowment because labour represented a key Democratic political constituency, the unions formed a core part of the old New Deal coalition, the leaders of the nation's largest federation of unions, the American Federation of Labor and Congress of Industrial Organizations (AFL-CIO) consistently supported Johnson's foreign policy adventures in Vietnam, and the theatre was the most highly organized art form in America (AFL-CIO Executive Council 1967: 1-2; Barkan 1967: 4-5). Labour certainly enjoyed a high symbolic status in the Johnson White House and the President frequently reached out to cement the support of the unions. In 1964 alone - admittedly an election year - Johnson invited labour leaders to a special White House dinner and an exclusive 
reception (Johnson 1964b; Johnson 1964c). By awarding such a large percentage of the agency’s funds to a heavily organized art form such as the theatre, the Endowment indicated subtle political commitments. The unions very obviously mattered in the Great Society world of the politics of art, particularly to congressional arts supporters such as Representative Frank Thompson Jr., a labour-backed Democrat from New Jersey, who, through the pages of Educational Theatre Journal, had long encouraged the nation's cultural leaders to seek 'better and more effective liaison with the great labor organizations' (in effect, to come together and lobby for more federal funds for the arts) (1957: 304).

In making awards to the theatre, the Endowment also demonstrated a marked preference for grants that fitted within the framework of Johnson's Great Society goals, specifically funds to deal with perceived problems of artistic scarcity by bringing the arts to the poor, to youth, and to predominantly African American audiences in urban areas. These priorities were wholly consistent with the aims of other Great Society programmes that targeted urban areas and increasingly ghettoized inner city populations (Piven and Cloward 2005: 253). Joseph Papp’s New York Shakespeare Festival, for example, received nearly half a million dollars from the Endowment in the space of just three years (namely an emergency grant of $\$ 100,000$ in fiscal year 1966, the same amount the following year, and \$250,000 in fiscal year 1968) (NEA 1967: 29, 1968: 44, 1969: 50). Despite the rather innocuous name, the New York Shakespeare Festival acted as a complex umbrella institution that sheltered a range of theatrical programming, including mobile tours that played in poverty-stricken areas, plus Spanish language productions in inner-city schools. Papp’s fiscal year 1969 grant application, for instance, outlined a five-city tour of the ghettoes with a fully integrated cast (1968). Chairman Stevens was thus no doubt 
exceedingly keen to assist Papp, precisely because the Festival delivered on Great Society goals by bringing the arts to those who were supposedly lacking in exposure to them.

The Laboratory Theatre for Education, one of the Endowment's early flagship projects, was also carefully designed to deliver on Great Society cultural goals, specifically to address problems of artistic scarcity by improving access to the arts: the programme aided disadvantaged and minority youth in their schooling through free theatrical performances for schools during the daytime, and outreach to poor adults with cheap tickets in the evenings (Senate Committee on Appropriations 1967: 1897-98). The agency contributed substantial sums to this project $\$ 330,000$ in fiscal year 1966, $\$ 681,000$ the next year, and another $\$ 135,750$ in fiscal year 1968 approximately 10 per cent of the Endowment's overall appropriation (NEA 1967: 29, 1968: 56, 1969: 67, 2016). The monies went to cities for urban uplift purposes: for example, one grant to Los Angeles was directed through the Inner City Cultural Centre, an organization founded in the wake of the Watts riots of 11-16 August 1965. Through exposing individuals to the arts, this laboratory aimed to dissipate the problems of the ghettoes and quell urban rioting by reaching atrisk, African American youth. By favouring organizations that wrapped themselves in Great Society rhetoric, the Endowment seemingly acted to deliver on Johnson's (admittedly hubristic) promise to bring 'an end to poverty and racial injustice [...] in our time' (1964a).

Through high-risk grants to potentially controversial theatres, the Endowment also expanded its constituency and brought radical theatre groups into the confines of Great Society liberalism. The agency's programmatic actions thus mimicked Johnson's personal desire to create consensus and bring a nascent New Left that stressed the ideals of participatory democracy, and was embodied in the grassroots social movements of the 1960s - particularly the anti-war, student, women's, and civil rights movements (and a recalcitrant older Left with 
intellectual roots based in New Deal beliefs about the power of the federal government to enact reforms from the top down) - into the remit of Great Society liberalism.

As Johnson escalated the Vietnam War, political tensions began to show in the experimental theatre world, as evidenced by plays such as Barbara Garson’s infamous MacBird! (1967), a satire of Shakespeare's Macbeth, wherein MacBird murders Ken O'Dunc (the former was meant to represent Johnson, the latter, John Kennedy). Although the Endowment did not fund this particular play, the agency made numerous politically high-risk grants to various experimental theatres in the later 1960s. In fiscal year 1968, for instance, the Endowment awarded \$84,750 to nine experimental organizations (NEA 1969: 50). Although a relatively small sum - just 1 per cent of the agency's overall budget - these grants held a high symbolic value (NEA 2016). Café LaMaMa, for instance, received an award of \$5000: this theatre was well known for what The New York Times termed 'far-out' plays, such as Paul Foster's Balls (1965), a show with a total cast of none, since the stage remained devoid of actors at all times (Keating 1965: X3). That same year, the Open Theatre also received a \$5000 grant from the Endowment: this group was similarly well known for controversial performances, most notably a production of Megan Terry's incendiary anti-war offering, Viet Rock: A Folk War Movie (1966), a play that directly attacked the Johnson administration's promulgation of the Vietnam War with slogans such as 'Let’s go gay with LBJ!' and 'I got syphilis today, courtesy, LBJ!' (Robertson 1967: 51; Brown 1967: 25). Although the Endowment did not specifically fund either Balls or Viet Rock, agency awards contributed to the survival of both experimental theatre groups, and thus, albeit indirectly, supported the production and creation of politically controversial works.

Potentially problematic Endowment grants did not, however, lead to major public rows in the later 1960s, because few knew exactly what the agency was funding. The language of 
plays like Viet Rock expressly mimicked the daily chanting of the New Left, the 'Hey, Hey, LBJ... How Many Kids Did You Kill Today?' that echoed outside the walls of the White House, but the Johnson administration was unaware of the Endowment's awards to politically explosive experimental theatre. Although The New York Times did cover the agency's first grants to 'strictly experimental theatre', Chairman Stevens was careful to downplay the 'experimental' element in public interviews, and the mainstream press made little attempt to discover exactly what 'experimental' meant (Robertson 1967: 51). Popular magazines such as Vogue regularly covered New York City's underground theatre scene, along with specialized theatre journals such as the Tulane Drama Review, but otherwise, very few national media outlets examined the Endowment’s support in the way of specific grants (Gruen 1968: 31; Smith 1966: 159-76).

All told, the Endowment's efforts to coopt radical art forms into a big-tent Great Society liberalism were reasonably successful in the mid-to-late 1960s. The experimental theatre gradually became more reliant on federal subsidy (and correspondingly less radical) once idealistic groups started to tailor their grant applications to serve the agency's goals and move out from the underground to the mainstream (which was arguably the point of the funding in the first place). Private and philanthropic monies helped too: in 1968, Ellen Stewart's Café La MaMa Experimental Theatre Club, for example, moved from a tiny coffeehouse one flight up from a drycleaners to a four-storey former meat-packing plant with the help of two substantial grants of $\$ 75,000$ from the Ford Foundation, and $\$ 65,000$ from the Rockefeller Foundation (Zolotow 1968: 49). Two years later, La MaMa debuted on Broadway with Julie Bovasso’s Gloria and Esperanza (1970), a fantastical play that dealt with themes of artistry and psychiatry (Barnes 1970: 32). As Stephen J. Bottoms has argued, what was once a subcultural phenomenon, a community theatre serving the immediate area of Greenwich Village, gradually became 
commercialized, as the anti-capitalist sentiment of the mid-1960s and efforts to create a free theatre basically gave way to a desire for assimilation into existing economic structures (2004: 270-73). As had been the case during the earlier Cold War years, the federal government helped transform the avant-garde into a new artistic establishment (Barnhisel 2015: 25-28).

\section{Fiscal fears trump thoughts of artistic scarcity in the later 1960s}

By 1968 inflation was undermining the national economy and Johnson only belatedly called for a tax hike. Although Congress supported this move, conservatives demanded big savings from non-essential Great Society programmes - and top of that list was the Endowment. Thus, although the agency's appropriations grew from less than \$3 million for fiscal year 1966, to nearly \$8.5 million in fiscal year 1967, Congress subsequently cut the Endowment’s funding to just over $\$ 7.5$ million for fiscal year 1968 (NEA 2016). As Brian Balogh has argued, politics itself was changing in the later 1960s because issues that were previously considered inappropriate for public action were now the source of new policy agendas, meaning that Congressmen increasingly found themselves micromanaging programmes and undertaking intensive oversight, as hearings became the venue for the articulation of new demands and the expansion of public policy through the exposure of federal failures (2005: 159, 167). Most notably, pertinent criticisms of the young Endowment came not just from the very few conservatives left in Congress (even after their ranks swelled, especially in the House following the 1966 midterms), but instead from liberals, Democrats, and other programmatic supporters.

Art was to many Congressmen now simply another unwarranted expenditure in the tougher economic climate of the later 1960s, and members needed to demonstrate fiscal responsibility. That was certainly the position taken by Representative Winfield Denton, a 
fiscally conservative Democrat from Indiana, and Chairman of the House Subcommittee on the Department of the Interior and Related Agencies Appropriations (the body that recommended the Endowment's budget). During congressional hearings in early 1966, Denton argued that the United States 'got along without [arts] funds' until relatively recently, and the country survived: he felt that federal monies might be better spent on practical action like fish hatcheries or the school milk programme, not wasted on the arts. Denton was determined to scrutinize the Endowment's grant-making priorities and thereby demonstrate effective management of the federal budget, as the following exchange from hearings indicates:

Mr. Stevens: Well, you would not want us to approve money until we had an appropriation. We could not do that.

Mr. Denton: No. But before we appropriate, we must know what the money is to be used for.

Mr. Stevens: Generally speaking, we are familiar with the needs in the arts.

Mr. Denton: Mr. Stevens, if we know what the money is going to be used for, the agency is pretty successful. If you say, give us the money and we will decide how it is going to be spent later, then there is trouble $[\ldots]$ we are not about to write you a blank check. (House Committee on Appropriations, Subcommittee on Department of Interior and Related Agencies Appropriations 1966: 290, 300-01)

Chairman Stevens believed that arts world experts understood the nation's artistic needs better than Congress, but Denton did not agree. Instead the Congressman sought to exercise the 
traditional congressional power of the purse and to hold the agency to account at a time when funds for domestic programmes were growing ever scarcer.

Congress was not above suggesting what kind of art the Endowment ought to fund either. Senator Claiborne Pell, the Chairman of the Senate Subcommittee on Arts and Humanities, was seemingly intent on micromanaging the Endowment's aesthetic priorities, and during congressional hearings in the summer of 1967, he asked the agency's Chairman what percentage of Endowment funds went to avant-garde, abstract and Modernist artists, compared with traditional, representational, and realist painters. Chairman Stevens attempted to hedge his bets with the argument that it is impossible to label artists: even Andrew Wyeth, the realist who painted the famous Christina's World (1948), Stevens contended, rejected the representational appellation. When Pell responded that this was a nonsensical argument and offered a definition of representational art as 'you know when it's right side up or not', Stevens was forced to offer a figure of approximately 75 per cent of Endowment grants to non-representational artists (Senate Committee on Labor and Public Welfare, Special Subcommittee on Arts and Humanities 1967: 376-78; Anon. 1967: 14). Pell personally preferred representational art, but more importantly, he was concerned that taxpayers' money be spread around equitably, and that a balance be maintained in the Endowment's programming, without one art form dominating another.

But although this was far from the first time that Congress had sought in some way or another to regulate the arts, the tone and substance of criticism directed at the Endowment was very different from earlier efforts. In the late 1940s and into the 1950s, staunch anti-communists such as Representative George Dondero, a right-wing Republican from Michigan, had taken to the House floor (and the national newspapers) to argue that abstract art was a conspiracy inaugurated in Moscow to spread Communism to the United States (de Hart Mathews 1976). A 
decade and a half later though, legislators wanted to see the results of domestic federal arts funding, hence congressmen were principally interested in exercising caution when appropriating monies. In short, the Endowment ran into difficulties after 1965 - as was the case with other, much larger Great Society projects (Medicare, the War on Poverty, federal aid to education) but these were brought on by problems of fiscal scarcity, rather than worries about Communist infiltration.

\section{Conclusion}

Ultimately, the measure to create the National Endowment for the Arts only passed Congress in the summer of 1965 because this was a highly unusual moment in American history. 1965 was a golden age of liberal opportunity, a time when Johnson perceived few limits to what the country might achieve under his leadership (Patterson 2012). Public confidence was riding high, the economy was good, and Americans demonstrated a remarkable faith in the capacity of the federal government to solve domestic problems, both real and perceived. Indeed, the political appeal of an agency that appeared to merge both newer, qualitative, and older, quantitative, liberal goals, could hardly have been missed by Johnson who, after all, spoke publicly of how the new federal arts agency would improve the material needs of struggling artist by funding previously 'obscure and unknown' talents, whilst also showering the American people with an abundance of new artistic pleasures, 'for it is, after all, the people who create' (Johnson 1965).

In terms of programming, the youthful Endowment offered a greater percentage of monies to well-organized lobbies and politically adept special interest groups such as the theatre, an art form that consistently received nearly a quarter of the agency's limited funds, no doubt due to the influence of a key element of the old New Deal liberal coalition, the organized labour movement. In these early days, the Endowment also rewarded projects that promised to deliver 
on Great Society aims and objectives, most notably funds to arts activities in the urban ghettoes to quell African American rioting. In addition, the agency made small, but highly symbolic experimental theatre grants to bring the New Left into a big tent form of liberalism.

Clearly, in the realm of the arts at least, the Great Society actively serviced predominantly liberal constituencies and practised a form of consensus liberalism that involved cementing the legacy of the New Deal (by making funds to a heavily unionized art form a priority), solidifying the Great Society (by funding projects for urban uplift), and coopting the New Left too (by taming experimental theatre). Put simply, the Endowment provided a space whereby three contradictory conceptions of liberalism might coexist. These tensions, or competing strands within the ideology itself, mattered little in 1965, at the height of the Great Society moment, although these cleavages became more prominent in the later 1960s and subsequent years. That said, Great Society liberalism was not damned from the outset: the Endowment survived the fiscal pressures of the end of the decade, and in the early-to-mid 1970s, the agency's budget grew and grew ever larger. Thus, whilst scholars such as Allen Matusow and Ronald Radosh have emphasized the ways in which the Vietnam War led to the unravelling of American liberalism, this finding does not hold true when one examines the cultural realm (Matusow 1984; Radosh 1996). Once signed into existence, most congressmen supported the Endowment, despite the best efforts of conservatives and other programme critics during the Culture Wars of the 1980s and 1990s.

\section{References}

Aarons, L. (1965), ‘ 4 more bills ask aid for arts, humanities’, Washington Post, 8 January, p. C20. 
AFL-CIO Executive Council (1967), “'Unhesitating Support' for LBJ on Vietnam', AFL-CIO Free Trade Union News, 22:3, March, pp. 1-2.

Andrew, J. (1998), Lyndon Johnson and the Great Society, Chicago: I. R. Lee.

Anon. (1965), 'Art aid bill approved in House', Washington Post, 16 September, p. D20. (1966), 'Government and the arts: How much to whom?’, Newsweek, 18 July, pp. 36-38. (1967), 'The congressional art critics', The Wall Street Journal, 6 September, p. 14.

Balogh, B. (2005), 'Making pluralism “Great”': Beyond a recycled history of the Great Society', in S. Milkis and J. Mileur (eds), The Great Society and the High Tide of Liberalism, Amherst: University of Massachusetts Press, pp. 145-81.

Barkan, A. (1967), 'Poll shows US workers support Johnson, AFL-CIO Policies', AFL-CIO Free Trade Union News, 22:8, August, pp. 4-5.

Barnes, C. (1970), ‘La Mama Presents ‘Gloria’’, The New York Times, 5 February, p. 32.

Barnhisel, G. (2015), Cold War Modernists: Art, Literature, and American Cultural Diplomacy, New York: Columbia University Press. 
Baumol, W. and Bowen, W. (1965), 'On the performing arts: The anatomy of their economic problems', The American Economic Review, 55:1/2, March, pp. 495-502.

--- (1966), Performing Arts, The Economic Dilemma: A Study of Problems Common to Theater, Opera, Music, and Dance, New York: Twentieth Century Fund.

Binkiewicz, D. Federalizing the Muse: United States Arts Policy and the National Endowment for the Arts, 1965-80, Chapel Hill: The University of North Carolina Press.

Bottoms, S. (2004), Playing Underground: A Critical History of the 1960s Off-Off-Broadway Movement, Ann Arbor: The University of Michigan Press.

Brown, K. (1967), 'Dada drama, Daddy’, Arts Magazine, 41:4, February, pp. 24-25.

Brustein, R. (1964), 'Art, non-art: The curse of official culture’, The New Republic, 7 November, pp. 85-86, 88, 90.

Califano Jr., J. (1991), The Triumph and Tragedy of Lyndon Johnson, New York: Simon \& Schuster.

Caute, D. (2008), The Dancer Defects: The Struggle for Cultural Supremacy During the Cold War, Oxford: Oxford University Press. 
Dallek, R. (2004), Lyndon B. Johnson: Portrait of a President, London: Penguin Books.

de Hart Mathews, J. (1976), 'Art and politics in Cold War America', American Historical Review, 81:4, October, pp. 762-87.

Democratic Party (1964), 'Democratic Party platform of 1964, August 24, 1964', http://www.presidency.ucsb.edu/ws/?pid=29603. Accessed 7 October 2016.

Fried, R. (1990), Nightmare in Red: The McCarthy Era in Perspective, Oxford: Oxford University Press.

Galbraith, J. (1958), The Affluent Society, Boston: Houghton Mifflin Company.

Getlein, F. (1965), 'Roger and the Rabbits', The New Republic, 3 April, pp. 25, 27-28.

Gottfried, M. (1969), A Theatre Divided: The Post-War American Stage, Boston: Little, Brown and Company.

Gruen, J. (1968), ‘Catnip overground’, Vogue, 15 January, p. 31.

Halberstam, D. (1972), The Best and the Brightest, London: Barrie \& Jenkins Ltd. 
House Committee on Appropriations, Subcommittee on Department of Interior and Related Agencies Appropriations (1966), Department of the Interior and Related Agencies Appropriations for 1967, Part 3: Related Agencies (Hearings, 89th Congress, 2nd Session, Part 3, 28 February) Washington, DC: House Committee on Appropriations, Subcommittee on Department of Interior and Related Agencies Appropriations. Y4.Ap6/1:In8/6/967/pt.3.

Hunter, M. (1965), '2 bills in House may bypass panel’, The New York Times, 9 September, p. 27.

Jacobs, J. (1967), 'What the federal arts program really means', Art in America, 55:2, MarchApril, pp. 25-26, 28-29.

Johnson, L. (1964a), 'Remarks at the University of Michigan, May 22, 1964', http://www.presidency.ucsb.edu/ws/?pid=26262. Accessed 7 October 2016.

(1964b), 'Remarks at a White House dinner for labor leaders, May 4, 1964', http://www.presidency.ucsb.edu/ws/?pid=26212. Accessed 7 October 2016.

(1964c), 'Remarks at a reception for a group of labor leaders, July 24, 1964', http://www.presidency.ucsb.edu/ws/?pid=26395. Accessed 7 October 2016.

(1965), 'Remarks at the signing of the Arts and Humanities Bill, September 29, 1965', http://www.presidency.ucsb.edu/ws/?pid=27279. Accessed 7 October 2016. 
(1972), The Vantage Point: Perspectives of the Presidency, 1963-1969, London: Weidenfeld \& Nicolson.

Kahn Jr., E. (1954), 'Closing and openings II’, The New Yorker, 20 February, pp. 41-42, 45-51, $54-55$.

Keating, J. (1965), 'Making it Off Off Broadway’, The New York Times, 25 April, pp. X1, X3.

Krenn, M. (2005), Fall-Out Shelters for the Human Spirit: American Art and the Cold War, Chapel Hill: University of North Carolina Press.

Matusow, A. (1984) The Unraveling of America: A History of Liberalism in the 1960s, New York: Harper \& Row Publishers.

National Endowment for the Arts (NEA) (1965), The First Annual Report, 1964-5, Washington, DC: National Endowment for the Arts/National Council on the Arts.

(1967), Annual Report for Fiscal Year 1966, Washington, DC: National Endowment for the Arts/National Council on the Arts.

(1968), Annual Report for Fiscal Year 1967, Washington, DC: United States Government Printing Office. 
(1969), Annual Report for Fiscal Year 1968, Washington, DC: United States Government Printing Office.

(2016), 'National Endowment for the Arts appropriations history', http://arts.gov/opengovernment/national-endowment-arts-appropriations-history. Accessed 7 October 2016.

National Foundation on the Arts and the Humanities (NFAH) Act 1965 (1966), United States Statutes at Large (79, Public Law 89-209, 29 September), Washington, DC: United States Government Printing Office, pp. 845-55.

Norton-Taylor, D. (1966), 'Roger Stevens, a performing art’, Fortune, 73:3, March, pp. 152-53, 192, 197-98, 200, 202, 204.

Papp, J. (1968), ‘New York Shakespeare Festival grant application’, 23 May, New York, Folder New York Shakespeare Festival, Box 15, Entry \#21, Subject Files of Chairman Roger Stevens, 1964-1969, National Foundation on the Arts and Humanities, Record Group 288, College Park: National Archives II.

Patterson, J. (1996), Grand Expectations: The United States, 1945-75, New York: Oxford University Press. (2012), The Eve of Destruction: How 1965 Transformed America, New York: Basic Books. 
Piven, F. and Cloward, R. (2005), 'The politics of the Great Society', in S. Milkis and J. Mileur (eds), The Great Society and the High Tide of Liberalism, Amherst: University of Massachusetts Press, pp. 253-69.

Powell, A. (1965), 'National Foundation on the Arts and Humanities Act of 1965', Congressional Record (111, House of Representatives, 89th Congress, 1st Session, 15 September), Washington, DC: United States Government Printing Office, pp. 23937-938.

Radosh, R. (1996), Divided They Fell: The Demise of the Democratic Party, 1964-96, New York: The Free Press.

Robertson, N. (1967), '9 theatre units get federal aid', The New York Times, 7 September, p. 51.

Rockefeller Brothers Fund, Inc. (1965), The Performing Arts: Problems and Prospects, New York: McGraw-Hill Book Company.

Rose, B. (1967), 'Shall we have a renaissance?’, Art in America, 55:2, March-April, pp. 30-39.

Sabato, L. (1991), Feeding Frenzy: How Attack Journalism Has Transformed American Politics, New York: The Free Press. 
Saunders, F. (1999), Who Paid the Piper?: The CIA and the Cultural Cold War, London: Granta Books.

Schlesinger Jr., A. (1956), ‘The future of liberalism: The challenge of abundance’, The Reporter, 3 May, pp. 8-11.

Schrecker, E. (1998), Many Are the Crimes: McCarthyism in America, Princeton: Princeton University Press.

Seidenbaum, A. (1965), 'Creative talk on art world’, Los Angeles Times, 11 October, pp. D1, D9.

Senate Committee on Appropriations (1967), Department of the Interior and Related Agencies Appropriations for Fiscal Year 1968, Part 2 (Hearings, 90th Congress, 1st Session, Part 2, 14 March), Washington, DC: Senate Committee on Appropriations. Y4.Ap6/2:In8/968/pt.2.

Senate Committee on Labor and Public Welfare, Special Subcommittee on Arts and Humanities (1967), Arts and Humanities Amendments of 1967, Part 2 (Hearings, 90th Congress, 1st Session, Part 2, 16 August), Washington, DC: Senate Committee on Labor and Public Welfare, Special Subcommittee on Arts and Humanities. Y4.L11/2:Ar7/5/pt.2.

Smith, K. (1967), 'Roger Stevens and President Lyndon Baines Johnson’, Oval Office, The White House, Washington, DC, 21 January, 4315-27a, Presidential Collection, Austin: Lyndon B. Johnson Presidential Library. 
Smith, M. (1966), 'The good scene: Off Off-Broadway’, Tulane Drama Review, 10:4, Summer, pp. 159-76.

Taubman, H. (1966), ‘Adventuresome course: Arts Endowment's bold, new grants show a willingness to take chances', The New York Times, 1 September, p. 31.

Thompson Jr., F. (1957), ‘The federal government’s role in art', Educational Theatre Journal, 9, 4, December, pp. 300-05.

Von Eckardt, W. (1966), 'Critics are discovering that Stevens is a swan', Washington Post, 30 October, p. G9.

Von Eschen, P. (2004), Satchmo Blows up the World: Jazz Ambassadors Play the Cold War, Cambridge: Harvard University Press.

Wallis, J. (2006), 'Table Ea698-703: Federal Government Expenditure, By Major Function: 1934-99 [OMB]', in S. Carter and R. Sutch (eds), Historical Statistics of the United States: Earliest Times to the Present, vol. 5, Cambridge: Cambridge University Press, pp. 105-106.

Zolotow, S. (1968), 'La Mama to get larger quarters’, The New York Times, 24 July, p. 49.

\section{Contributor details}


Karen Patricia Heath holds a D.Phil. in Modern History from the University of Oxford. She is a Tutor in History and Politics for the University of Oxford, Department for Continuing Education, and History Tutor at St. Clare's, Oxford. Her research interests include modern American liberalism and conservatism, governmental growth, and the place of the arts in public life. She is currently preparing a book manuscript, provisionally entitled Conservatives and the Politics of Federal Arts Funding, from the Great Society to the Culture Wars.

Contact:

St. Clare’s, Oxford, 18 Bardwell Road, Park Town, Oxford, OX2 6SP, UK. E-mail: karen.heath@stclares.ac.uk

\section{Acknowledgments}

This article was written with the support of St. Anne's College and the Rothermere American Institute, University of Oxford. Additional funds were provided by the American Politics Group (Ros Davies Memorial Research Travel Award) and the British Library (Eccles Centre Postgraduate Award in North American Studies). Earlier versions were presented at the annual conferences of the American Politics Group and Historians of the Twentieth Century United States, the Policy History conference, and the Biennial Queen Mary Symposium in American History. Much of the research was conducted at the Vere Harmsworth Library (where I am particularly grateful to Jane Rawson for her assistance with congressional materials), St. Anne’s College Library, and Nuffield College Library, University of Oxford, plus the British Library, London. I am appreciative too of the assistance extended to me by the staff and archivists at the Lyndon B. Johnson Presidential Library, Austin, Texas, and the National Archives II, College 
Park, Maryland. Lastly, may I express my gratitude to my D.Phil. supervisor, Dr. Gareth Davies, for his detailed comments on earlier drafts, and to the editors, Stuart Barker and Nicholas Blower, and reviewer, Dr. Nick Witham, for their insightful comments also. 